\title{
DISPLACEMENT AMPLITUDES OF FORCED VIBRATION IN DOUBLE-SLOPE SIN GIRDERS WITH SEMIRIGID JOINT
}

\begin{abstract}
Displacement amplitudes of forced vibration in SIN girders with semirigid joint depend on the stiffness of the girder and the rotational stiffness of joints. Rotational stiffness has a decisive effect on the overall integrated stiffness of the girder. In addition, damping caused by semirigid joints produces differences in the frequency and amplitude of vibration. Therefore, an analysis of oscillatory motion in double-slope beams with corrugated web with semirigid joints in the mid-span was conducted. On the basis of dynamic experimental testing of three simply supported double-slope beams with corrugated web, rotational stiffness was determined for six joints. Using the theoretical models, namely the Kelvin-Voigt viscoelastic material and the standard one, differences in the displacement amplitude behaviour, damping and forces were shown. The investigations concerned girders with corrugated web for variable rotational stiffness of the joints under the action of the assumed excitation force.
\end{abstract}

Keywords: SIN girders, semirigid joints, rotational stiffness, viscoelastic material model

\section{Introduction}

For double-slope SIN girders with semirigid joint, which are in forced vibration, displacement amplitudes depend on the integrated stiffness of the $K$ girder. Double-slope of the girder improves the rotational stiffness of the $S j$ joint, which increases the overall integrated stiffness of the $K$ girder and affects the displacement amplitude in forced vibration. Variation in the rotational stiffness of the semirigid joint produces differences in damping, which affects forced vibration frequency in SIN girders with various types of semirigid joint in the mid-span.

The analysis was conducted on three simply supported double-slope girders with the corrugated web WTA 500/300x15 with the span of $6.02 \mathrm{~m}$ (Fig. 1).

${ }^{1}$ Author for correspondence: Witold Basiński, Silesian University of Technology, 44-100 Gliwice, ul. Akademicka 5, +48 32 2371127, witold.basinski@polsl.pl 
In the initial stage, the rotational stiffness of semirigid end-plate joints found in the girders was determined on the basis of vibration measurements. [1]. The rotational stiffness of joints was determined for three different mass loads $m_{i}$.

The behaviour of displacement amplitudes in forced vibration in doubleslope girders with the corrugated web was presented using two theoretical viscoelastic models of the material, namely the Voigt-Kelvin model and the standard one. The differences that resulted from the application of the two models of the material were shown.

The difference in magnitude of amplitude and damping while using the semirigid joints with variable rotational stiffness for different mass loading under the action of the assumed excitation force was determined.

\section{Experimental determination the rotational stiffness of joints}

For the investigations, models of double-slope girders were built using two independent, mirror-image shipment elements WTA 500/300x15. The shipment elements were connected by semirigid end-plate joints. As a result, three simply supported double-slope girders with the span of $6.02 \mathrm{~m}$ and the inclination angle of $10^{\circ}$ were produced (Fig. 1 ).

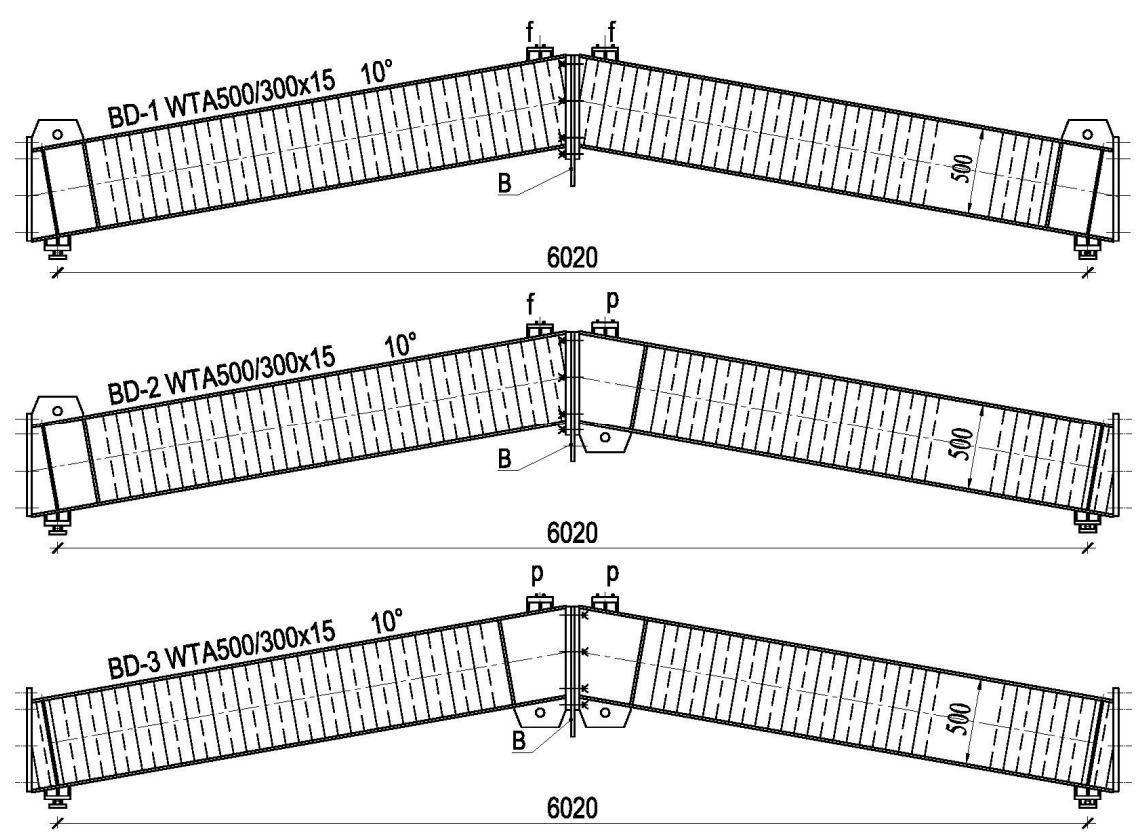

Fig. 1. Double-slope girders with corrugated web

Rys. 1. Dwuspadowy dźwigar ze środnikiem z blachy fałdowej 
Webs and flanges of the double-slope girders were made of S235 steel. Rotational stiffness was determined for three types of end-plate joints:

1) with the corrugated web in contact with the end-plate on both sides of the $\mathrm{f}-\mathrm{f}$ joint; 2) with a section of the flat web on one side of the joint and the corrugated web in contact with the end-plate on the other side of the p-f joint; 3 ) with a section of the flat web on both sides of the p-p joint (Fig.2)

a)

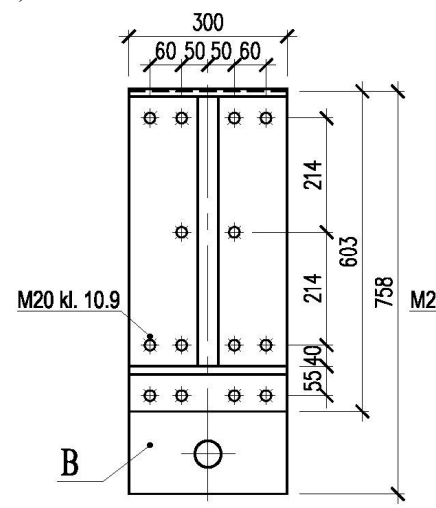

b)

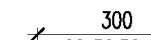

c)

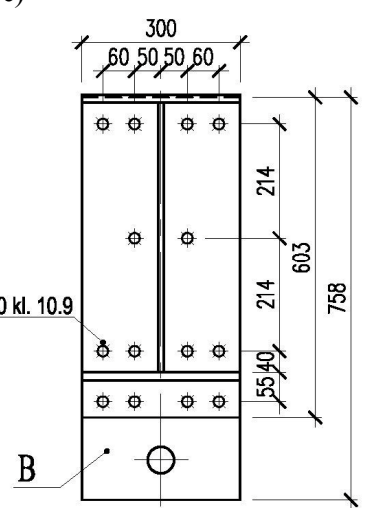

Fig. 2. End-plate joints in double-slope girders a) $f-f$ in BD-1; b) p-f in BD-2; c) p-p in BD-3

Rys. 2. Połączenia doczołowe dźwigara dwuspadowego a) f-fw BD-1; b) p-fw BD-2; c) p-p w BD-3

In the end-plate joints of concern, the plates were $30 \mathrm{~mm}$ in thickness. The additional separator plate $\mathrm{B}$, with the thickness of $20 \mathrm{~mm}$, was necessary so that mass load $m_{i}$ could be suspended The joints were was bolted with 10.9 grade M20 bolts. The tightening moment of $M_{s}=120 \mathrm{Nm}$ was used to preload the bolts. That constituted $11 \%$ of the allowable strength of the bolt and made it possible to consider the joint semirigid. After the end-plates were bolted, no assembly deviations were observed.

The models of double-slope girders were installed on the test stand (Fig. 3). The test stand was built from concrete blocks (1), on which immovable (2) and movable (3) hinge supports were placed.

Three different mass loads of $421 \mathrm{~kg}, 1218 \mathrm{~kg}$, and finally $2349 \mathrm{~kg}$ were suspended from the double-slope girder via plate $\mathrm{B}$ and a rigid joint made from 120x120x15 (4) angles. Mass loads $m_{i}$ suspended from the double-slope girder were supported, via a $30 \mathrm{~mm}$ diameter steel ball, by a $\varphi 50$ tube going through the large force plate.

In the tests, a short duration dynamic impulse of was introduced by means of rapid elimination of the support under the mass load. Using the vibration analyzer (5), frequency, amplitude and acceleration of vertical damped free vibration of the girder - mass load $m_{i}$ system were measured. 

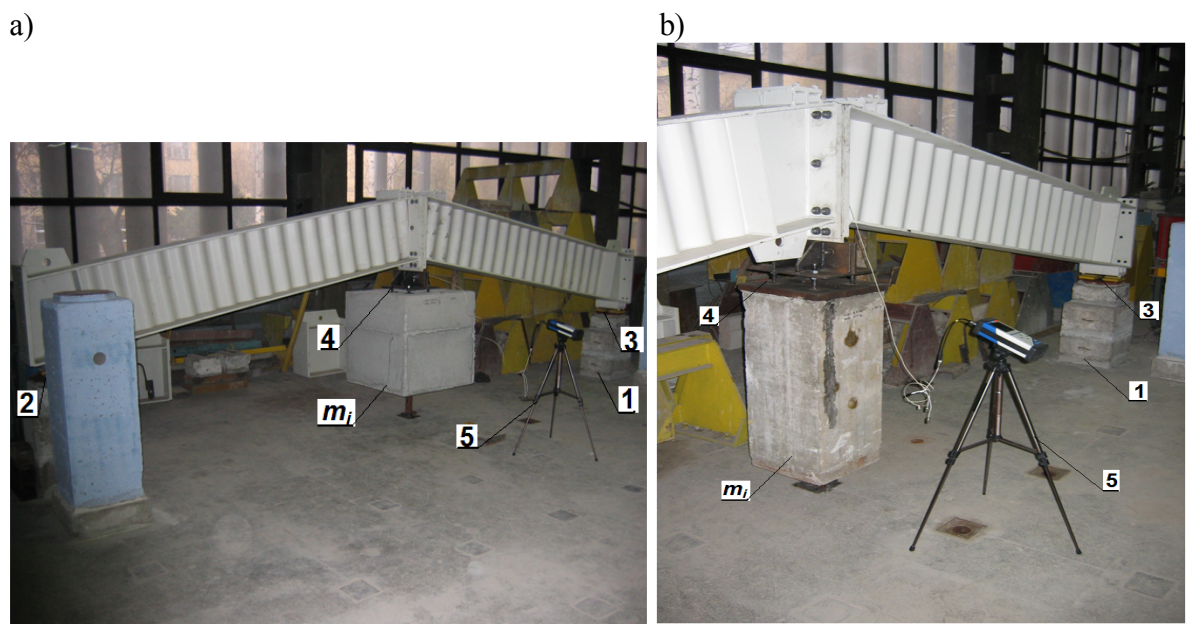

Fig. 3. Double-slope girders on the test stand in vibration measurement tests a) BD-1 with the mass of $1218 \mathrm{~kg}$; b) BD-2 with the mass of $421 \mathrm{~kg}$

Rys. 3. Dwuspadowe dźwigary na stanowisku badawczym podczas pomiaru wibracji

a) dźwigar BD-1 z obciążeniem o masie 1218 kg; b) BD-2 z obciążeniem o masie 421 kg;

On the basis of the measured dynamic parameters and the dynamic method, in accordance with [1], the rotational stiffness $S j$ of $\mathrm{f}-\mathrm{f}, \mathrm{p}-\mathrm{f}$ and p-p joints was determined for successive mass loads applied to double-slope girders. Rotational stiffness results, smoothed with the regression curve, are presented in Table 1.

Table 1. Rotational stiffness of end-plate joints of the girder

Tabela 1. Sztywność giętna połączenia doczołowego w dźwigarze

\begin{tabular}{|c|c|c|}
\hline Model & Type of the joint & $\begin{array}{c}\text { Rotational stiffness } \\
S_{j} \\
{[\mathrm{kNm} / \mathrm{rad}]}\end{array}$ \\
\hline 1 & 2 & 3 \\
\hline BD-1 WTA/500x300x15 & f-f & 221402 \\
\hline BD-2 WTA/500x300x15 & p-f & 254325 \\
\hline BD-3 WTA/500x300x15 & p-p & 270257 \\
\hline
\end{tabular}

\section{Displacement amplitudes in double-slope girders in accor- dance with the Voigt-Kelvin model}

In the first case, displacement amplitudes of double-slope girders in the forced motion were determined using the Voigt-Kelvin model, widely applied for studying viscoelastic materials (Fig. 4). The model is characterised by the occurrence of time delay with respect to the load applied. 
a)

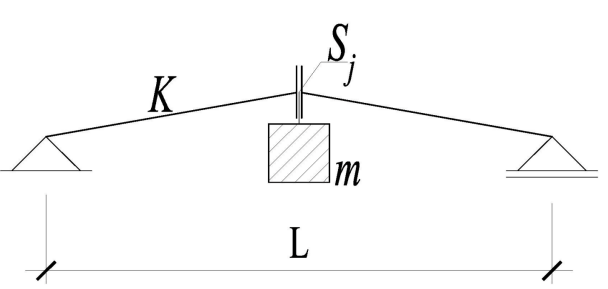

b)

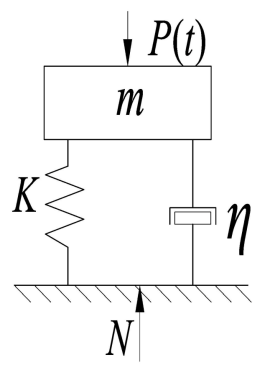

Fig. 4. Schema: a) double-slope girder; b) the Voigt - Kelvin material model

Rys. 4. Schemat: a) dźwigara dwuspadowego b) modelu materiałowego Voigta - Kelvina

In the Voigt-Kelvin model, the differential equation of displacements $q(t)$ of harmonically forced oscillatory motion has a widely known form [4] (1):

$$
m \cdot \frac{d^{2}}{d t^{2}} q(t)+\eta \cdot \frac{d}{d t} q(t)+K \cdot q(t)=P_{o} \cdot \cos (\Omega \cdot t)
$$

where: $P_{o}$ - excitation force $\Omega$ - excitation frequency, $K$ - the system stiffness, $\eta-$ viscosity coefficient.

The displacement amplitude $A_{V}$ of mass $m$ in harmonic forced vibration in the steady state according to the Voigt-Kelvin model, which is a part of the general integral representing the displacement $q(t)$ of mass $m$, is determined from the dependence (2):

$$
A_{V}=\frac{P_{o}}{\left(-m \cdot \Omega^{2}+1 i \cdot \eta \cdot \Omega+K\right)}
$$

where $i=\sqrt{-1}$.

The profiles of motion and displacement amplitude in forced motion were presented for double-slope girders with the following corrugated webs: BD-1 with the f-f joint, BD-2 with the p-f joint, and BD-3 with the p-p joint. For the theoretical analysis, the parameters given in Table 2 were assumed. Those included the following: excitation force $P_{o}$; mass of the suspended mass load $m_{i}$, concentrated mass $m$ of the system, which accounted for the mass of the mass load $m_{i}$ and equivalent concentrated mass of the girder $m_{z}$, viscosity coefficient $\eta$; integrated stiffness of the girder - mass system and the frequency of undamped free vibration $\omega$. The data in Table 2 were assumed on the basis of dynamic tests of SIN girders discussed in the paper [1]. 
Table 2. Parameters of double-slope SIN girders used in the dynamic analysis

Tabela 2. Parametry dwuspadowego dźwigara SIN użytego w analizach dynamicznych

\begin{tabular}{|c|c|c|c|c|c|c|c|}
\hline Model & $\begin{array}{l}\text { Type } \\
\text { of the } \\
\text { joint }\end{array}$ & $\begin{array}{c}P_{o} \\
{[\mathrm{kN}]}\end{array}$ & $\begin{array}{c}m_{i} \\
{[\mathrm{~kg}]}\end{array}$ & $\begin{array}{c}m \\
{[\mathrm{~kg}]}\end{array}$ & $\begin{array}{c}\eta \\
{[\mathrm{kg} / \mathrm{s}]}\end{array}$ & $\begin{array}{c}K \\
{[\mathrm{kN} / \mathrm{m}]}\end{array}$ & $\begin{array}{c}\omega \\
{[\mathrm{rad} / \mathrm{s}]}\end{array}$ \\
\hline 1 & 2 & 3 & 4 & 5 & 6 & 7 & 8 \\
\hline \multirow{3}{*}{$\begin{array}{c}\text { BD-1 } \\
\text { WTA/500x300x15 }\end{array}$} & \multirow{3}{*}{$f-f$} & 50 & 421 & 851 & 760 & $1.5154 * 10^{7}$ & 133.444 \\
\hline & & 50 & 1218 & 1648 & 1041 & $1.5391 * 10^{7}$ & 96.640 \\
\hline & & 50 & 2349 & 2779 & 920 & $1.5046^{*} 10^{7}$ & 73.581 \\
\hline \multirow{3}{*}{$\begin{array}{c}\text { BD-2 } \\
\text { WTA/500x300x } 15\end{array}$} & \multirow{3}{*}{$p-f$} & 50 & 421 & 881 & 311 & $1.5691 * 10^{7}$ & 133.456 \\
\hline & & 50 & 1218 & 1678 & 639 & $1.5672 * 10^{7}$ & 96.642 \\
\hline & & 50 & 2349 & 2809 & 886 & $1.5491 * 10^{7}$ & 74.262 \\
\hline \multirow{3}{*}{$\begin{array}{c}\text { BD-3 } \\
\text { WTA/500x300x } 15\end{array}$} & \multirow{3}{*}{$\mathrm{p}-\mathrm{p}$} & 50 & 421 & 908 & 268 & $1.6171 * 10^{7}$ & 133.452 \\
\hline & & 50 & 1218 & 1705 & 451 & $1.5924 * 10^{7}$ & 96.642 \\
\hline & & 50 & 2349 & 2836 & 850 & $1.5932 * 10^{7}$ & 74.952 \\
\hline
\end{tabular}

The profile of motion $q(t)$ of double-slope girders built from Voigt-Kelvin material was shown on the example of BD-1 girder for the mass load of $m_{i}=1218 \mathrm{~kg}$, which gives concentrated mass of the system of $m=1648 \mathrm{~kg}$, when the equivalent concentrated mass is taken into account. For the selected parameters, the displacement of the concentrated mass of the system $m$ of the BD-1 girder with the f-f joint in resonance excitation takes, in the initial stage and in the steady state, the form shown in Fig.5 (with zero initial conditions $q_{o}=0$ and $v_{o}=0$ ).

a)

b)

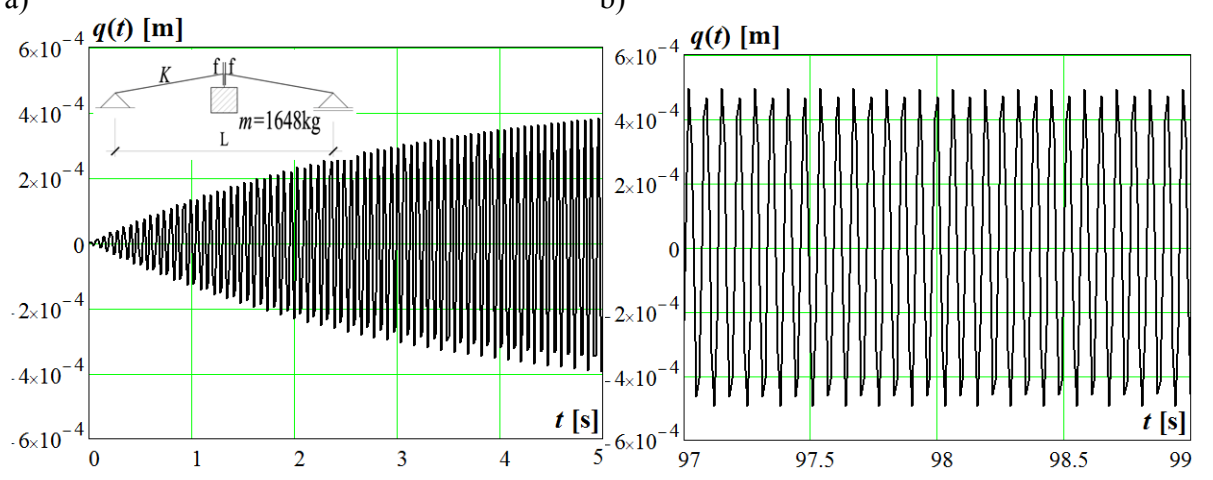

Fig. 5. Graphs presenting the displacements in the initial phase and the steady state of concentrated mass $m$ of the system girder + mass loading of the BD-1 gabled SIN girder with f-f joint

Rys. 5. Graficzna prezentacja przemieszczeń w stanie początkowym i w stanie ustalonym masy skupionej $m$ układu obciążenia masa + dźwigar, dwuspadowego dźwigara SIN z węzłem typu f-f 
Displacement amplitudes in forced motion for BD-1, BD-2 and BD-3 girders were determined, in accordance with the Voigt-Kelvin material model, for successive mass loads $m_{i}$ used in the tests. At the initial stage of the oscillatory motion of double-slope girders with the corrugated web in resonance excitation, the so-called is "quasi-beat" character of motion about low intensity is found. (Fig. 5a). This effect is attenuated in the steady state of the motion. The "quasi-beat" phenomenon can be eliminated by increasing the rotational stiffness $S_{j}$ of the joint, thus decreasing damping, and also enhancing the integrated stiffness of $K$ girder.

Displacement amplitudes were determined for the steady state of motion at variable excitation frequency including the resonance range. Graphs showing the profile of displacement amplitudes as a function of excitation frequency for double-slope girders with the corrugated web are presented in Fig 6.

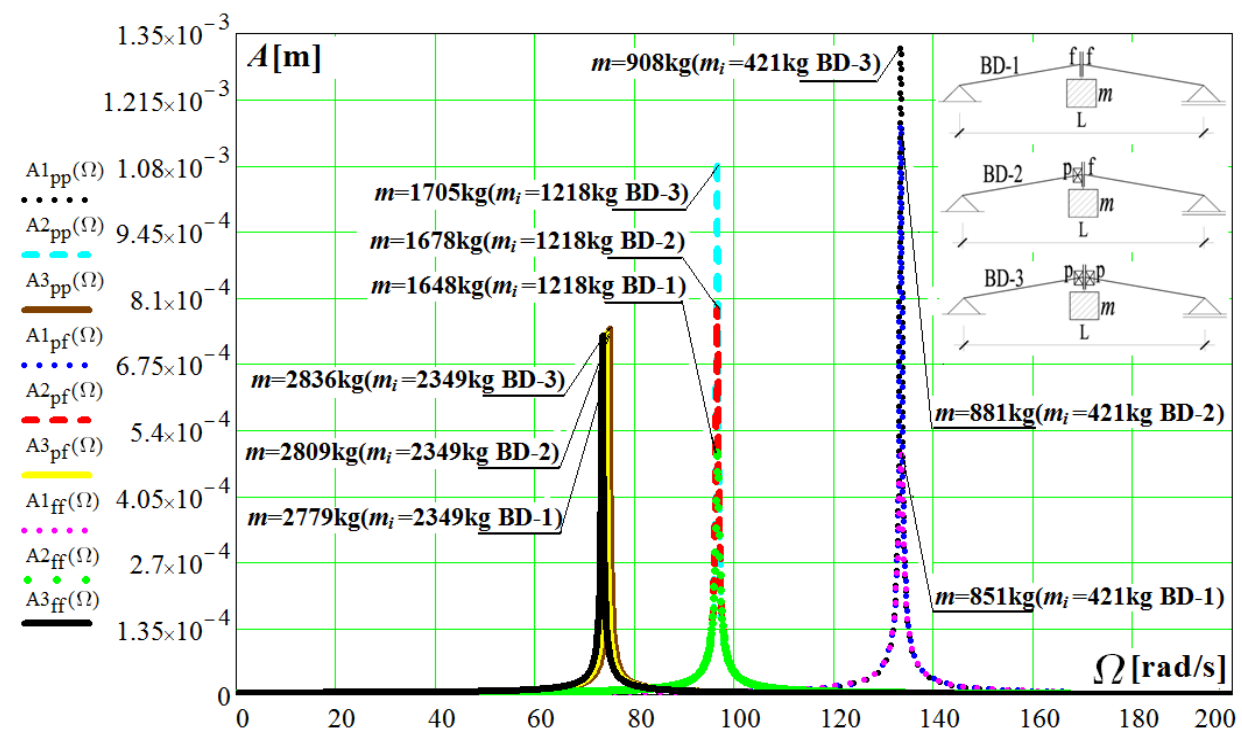

Fig. 6. Displacement amplitudes $A_{V}$ of the concentrated mass $m$ of the girder - mass load $m_{i}$ system for double-slope SIN girders according to the Voigt-Kelvin material model

Rys. 6. Amplitudy przemieszczeń $A_{V}$ masy skupionej $m$ układu obciążenia dźwigar + masa $m_{i}$ dla dwuspadowego dźwigara SIN według modelu materiałowego Voigta - Kelvina

The maximum displacement amplitudes occur in resonance excitation with the first vibration frequency. In the double-slope girders with mass loads of $m_{i}=421 \mathrm{~kg}$ and $m_{i}=1218 \mathrm{~kg}$, the resonance phase shift is not observed. The minimal resonance phase shift occurs only for the mass load of $m_{l}=2349 \mathrm{~kg}$. In all double-slope girders, however, a noticeable difference in deflection values occurs. The highest deflection values were found for the BD-3 girder with the stiffest p-p joint. Decrease in the values of amplitude is accompanied 
by a decrease in the rotational stiffness of the joint, which lowers the integrated stiffness of the $K$ girder. The effect of joint stiffness fades away with an increase in mass load.

Additionally, increased stiffness of the joint produces a decrease in damping viscosity $\eta$, which in turn results in higher deflection values (amplitudes) generated in the structure in harmonic excitation.

\section{Displacements amplitudes in double-slope girders in accor- dance with the standard model}

To check the usability of the solution obtained with the Voigt-Kelvin model, in the second analysis of double-slope girders in forced motion, displacement amplitudes were estimated on the basis of the standard model (Fig. 7). The model is constructed by combining, in series, the Hook model and the Voigt-Kelvin model. In the resultant model, an instantaneous displacement is found, which is correlated to the load applied. Such a situation is always observed in steel structures. Thus, the standard model is the first and the simplest tool that can be used to estimate instantaneous displacements.

a)

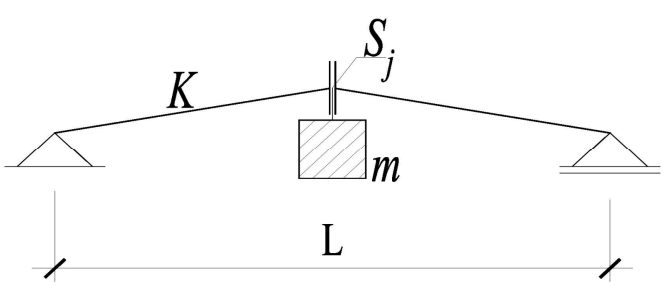

b)

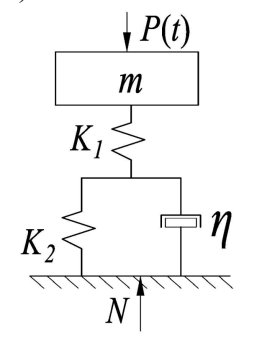

Fig. 7. Schema: a) double-slope girder; b) Standard material model

Rys. 7. Schemat: a) dźwigara dwuspadowego b) standardowego modelu materiałowego

In the standard model, the differential equation of the displacement $q(t)$ of harmonically forced oscillatory motion is expressed by the equation [5] (3):

$$
\begin{aligned}
& \frac{d^{3}}{d t^{3}} q(t)+\frac{\omega_{1}^{2}+\omega_{2}^{2}}{2 \cdot \rho_{v}} \cdot \frac{d^{2}}{d t^{2}} q(t)+\omega_{1}^{2} \frac{d}{d t} q(t)+\frac{\omega_{1}^{2} \cdot \omega_{2}^{2}}{2 \cdot \rho_{v}} \cdot q(t)= \\
& \frac{P_{o}}{m} \cdot\left(\frac{\omega_{1}^{2}+\omega_{2}^{2}}{2 \cdot \rho_{v}} \cdot \sin (\Omega \cdot t)+\Omega \cdot \cos (\Omega \cdot t)\right)
\end{aligned}
$$

where: $\rho_{v}=\eta / 2 m$ - damping corresponding to the damping in the Voigt-Kelvin model, $\omega_{1}, \omega_{2}-$ frequency of vibration of the first and the second spring according to (4): 


$$
\omega_{1}=\sqrt{\frac{K_{1}}{m}} \quad \text { oraz } \quad \omega_{2}=\sqrt{\frac{K_{2}}{m}}
$$

Amplitude of displacement $A_{S}$ of mass $m$ of harmonic forced vibration in the steady state in the standard model, which is a part of the general integral determining the displacement $q(t)$ of mass $m$, is determined from the following equation (5):

$$
A_{S}=\frac{P_{o} \cdot\left(m \cdot \omega_{1}^{2}+m \cdot \omega_{2}^{2}+\Omega \cdot \eta\right)}{\left[m \cdot\left(-i \cdot \Omega^{3} \cdot \eta-m \cdot \Omega^{2} \cdot \omega_{1}^{2}-m \cdot \Omega^{2} \cdot \omega_{2}^{2}+i \cdot \omega_{1}^{2} \cdot \Omega \cdot \eta+\omega_{1}^{2} \cdot \omega_{2}^{2} \cdot m\right)\right]} .
$$

The profile of motion $q(t)$ for double-slope girders built from the standard material was presented in the same way as it was the case for the Voigt-Kelvin material model, i.e. on the example of the BD-1 girder with the mass load of $m_{i}=1218 \mathrm{~kg}(m=1648 \mathrm{~kg})$ The division of integrated stiffness of $K$ girder into $K_{2}=(20 / 19) K$ and $K_{1}=20 K$ was assumed. On the basis of viscosity $\eta$ determined in the tests, damping $\rho_{v}$ assumed in the standard model corresponded to damping in the Voigt-Kelvin model.

For the parameters listed in Table 2, the displacement of the concentrated mass of the BD-1 girder and the f-f joint system in resonance excitation, at the initial stage and in the steady state, has a form presented in Fig. 8. (assuming the initial zero conditions $q_{o}=0, v_{o}=0$ and $a_{o}=0$ ).

a)

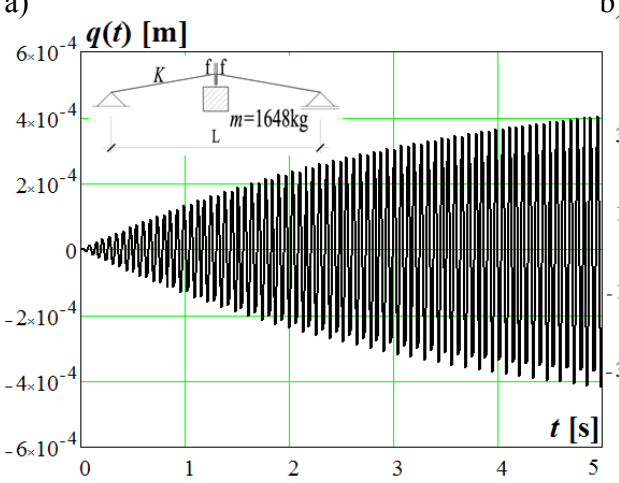

b)

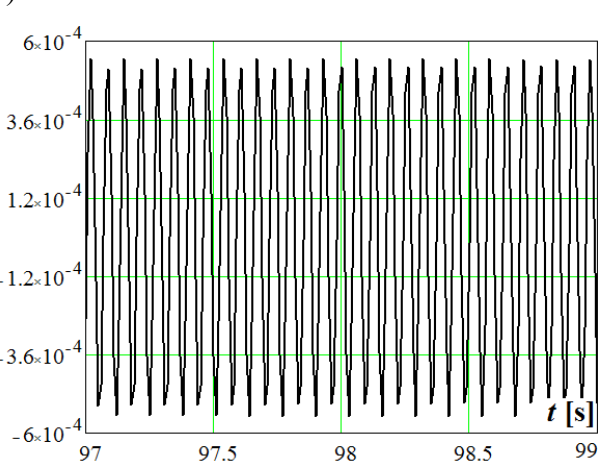

Fig. 8. Graphs of displacements of the concentrated mass $m$ of the girder and mass load system in the initial stage and the steady state for BD-1 double-slope girder with the f-f joint.

Rys. 8. Graficzna prezentacja przemieszczeń masy skupionej $m$ układu obciążenia masa + dźwigar, w stanie początkowym i w stanie ustalonym dwuspadowego dźwigara BD-1 z węzłem typu f-f

The profile of motion of double-slope girders in excitation obtained with the standard material model is similar to that produced when the Voigt-Kelvin 
material model was used. The minimal effect of the so-called "quasi-beat" occurs only at the initial stage. This unfavourable effect, which can lead to the superposition of successive vibration waves, disappears when the stiffness of the joint (and thereby the stiffness of the girder) increases. As it was the case with the Voigt-Kelvin material model, in the steady state, "quasi-beat" fades away.

Amplitude and frequency analysis conducted in accordance with the standard material model concerned BD-1, BD-2 and BD-3 double-slope girders, to which three mass loads, namely $m_{i}: 421,1218$ and $2349 \mathrm{~kg}$ were applied in the tests. Displacement amplitudes in the steady motion were determined from the dependence (5). Graphs showing the dependence of displacement amplitude on the excitation frequency are presented in Fig.9.

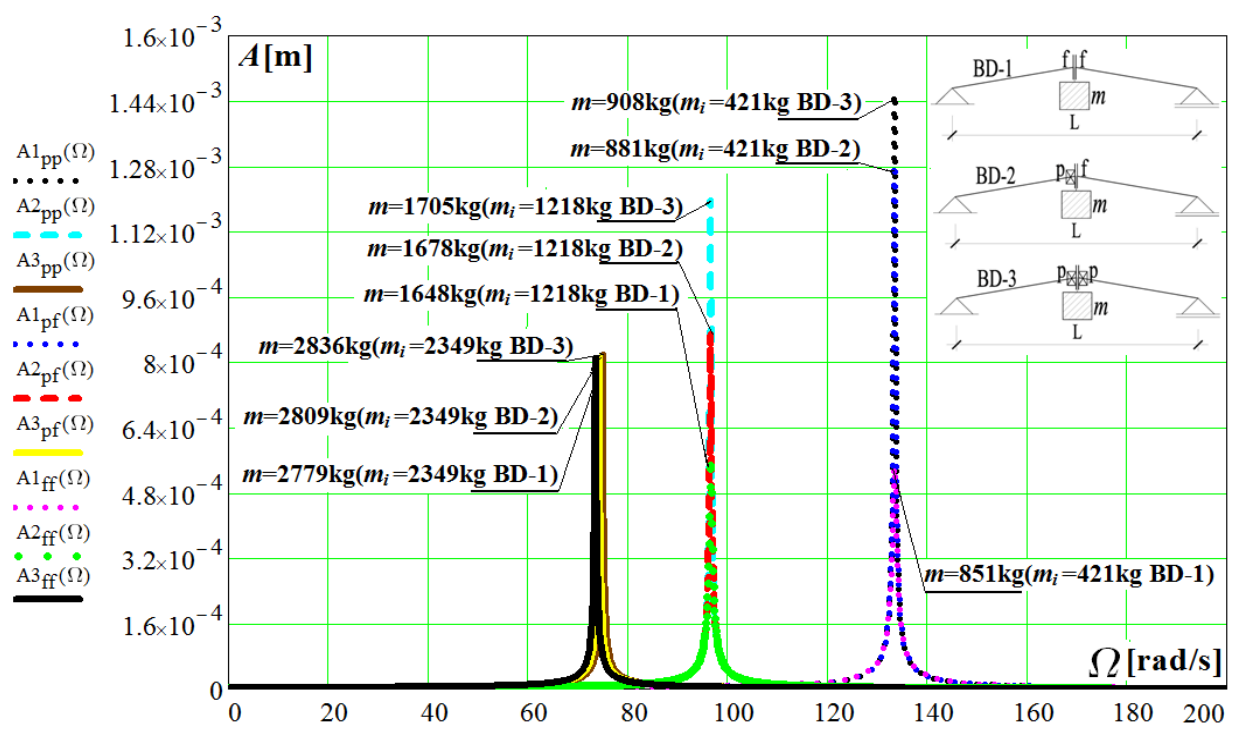

Fig. 9. Displacement amplitudes $A_{s}$ of the concentrated mass $m$ of the girder - mass load $m_{i}$ system for double-slope girders according to the standard material model

Rys. 9. Amplitudy przemieszczeń $A_{V}$ masy skupionej $m$ układu obciążenia dźwigar + masa $m_{i}$ dla dwuspadowego dźwigara według standardowego modelu materiałowego

When the standard material model is applied, all double-slope girders with the flexible joint reach the maximum amplitude due to the excitation force of the same excitation frequency as for the Voigt-Kelvin material model. It should be added that for the standard material model, free vibration frequencies $\omega_{l}$ and $\omega_{2}$, differ from those for the Voigt-Kelvin material model, which is due to stiffness $K$. Additionally, the maximum displacement amplitude occurs in the final stage in steady motion at free vibration frequency of $\omega$ corresponding to the resonance frequency. 
When the standard model is used, like for the Voigt-Kelvin material model, no clear resonance phase shift is observed in double-slope girders. Additionally, in all double-slope girders, a noticeable difference in the magnitude of amplitudes can be seen for the standard model. The highest values are found for the BD-3 girder with the most rigid p-p joint. In addition, as a result of the influence of damping on displacement amplitudes, the BD-1 girder with the f-f joint, in which greater damping occurred, showed considerably lower values of displacement amplitude in forced motion. As regards BD-3 and BD-1 girders, the maximum ratio of amplitudes amounted to $284 \%$.

For both models, an increase in the joint stiffness, and consequently reduction in damping, resulted in higher deflection of the structure in harmonic excitation, e.g. due to the action of gust of wind. It should be added that for the standard model, displacement amplitudes of harmonically forced oscillatory motion are up to $11 \%$ higher than in the case of the Voigt-Kelvin model.

\section{Conclusions}

Maximum displacement amplitudes in double-slope girders with the corrugated web built from the Voigt-Kelvin material and the standard one depend on the integrated stiffness of $K$ girder, which is affected by the rotational stiffness of joint $S_{j}$ and damping. Therefore, increasing joint stiffness results in damping decrease. Consequently, by controlling joint stiffness it is possible to control damping, and thereby displacement amplitudes in harmonically forced motion. That plays an important role when the structure is under cyclic load, such as e.g. gusts of wind.

For both the Voigt-Kelvin material model and the standard one, double-slope girders with the corrugated web with the semirigid joint reach the maximum displacement amplitudes in harmonically forced oscillatory motion at resonance excitation corresponding to the free vibration frequency $\omega$.

The maximum amplitude for the BD-3 double-slope girder with the p-p joint proved to be $284 \%$ higher than the displacement amplitude of the BD-1 double-slope girder with the f-f joint. The resonance phase shift was not observed in the doubleslope girders with the corrugated web.

The comparison of the vibration amplitude in girders built in accordance with the Voigt-Kelvin material model and the standard one shows that displacement estimated on the basis of the standard material model is up to $11 \%$ greater than it was the case for the Voigt-Kelvin material model.

\section{Bibliography}

[1] Basiński W. Determination of the rotational stiffness of semirigid end joints in metallic structures based on the measured vibrations. PhD thesis. Silesian University of Technology. Gliwice 2006 (in Polish). 
[2] Basiński W. Analysis of changes in the frequency of vibration of circular beams with semirigid joint in the middle of the span. Rzeszów - Bezmiechowa Conference 2008 (in Polish).

[3] Basiński W. Amplitude of displacements of simply supported SIN girders with semirigid joint. Proceedings of the 12th International Conference on New Trends in Statics and Dynamics of Buildings, Bratislava, October 16-17, 2014.

[4] Chmielewski T. Zembaty Z.: Basics of building dynamics. Arkady. Warszawa1998 (in Polish).

[5] Kowal Z.: The dynamics of a weightless beam on viscoelastic supports. Archives of Civil Engineering. Volume XII, 1/1966 (in Polish).

[6] Langer J.: The dynamics of the building. Wroclaw University of Technology Publishing House. Wrocław 1980 (in Polish).

[7] Novak R. - Machacek J.: Design resistance of undulating webs under patch loading. Proceedings of the Third International Conference on Coupled Instabilities in Metal Structures VIMS 2000, Lisbon, Portugal 2000.

[8] Profile of corrugated web of SIN. Principles of dimensioning. Cracow University of Technology. Cracow 2002 (in Polish).

[9] EN 1993-1-5. Eurocode 3: Design of steel structures. Part 1.5: Plated structural elements. 2008.

\section{AMPLITUDY PRZEMIESZCZEŃ DRGAŃ WYMUSZONYCH W DWUSPADOWYCH DŹWIGARACH SIN Z WEZZEEM PÓLSZTYWNYM}

\section{Streszczenie}

Amplitudy przemieszczeń drgań wymuszonych w dźwigarach SIN z połączeniem półsztywnym zależą od sztywności dźwigara i sztywności giętej węzłów. Sztywność giętna ma decydujący wpływ na całkowitą sztywność dźwigara. W dodatku, tłumienie spowodowane przez węzły półsztywne powoduje różnice częstotliwości i amplitudy drgań. Dlatego, przeprowadzono analizę ruchu wahadłowego dwuspadowych belek $\mathrm{z}$ falistym środnikiem i półsztywnym węzłem w środku rozpiętości. Na podstawie doświadczalnych badań dynamicznych, trzech swobodnie podpartych belek dwuspadowych ze środnikiem z blachy falistej, określono sztywność giętną sześciu połączeń. Wykorzystując materiałowe modele teoretyczne, mianowicie lepkosprężysty model Kelvin-Voigt oraz model standardowy, wykazano różnice w zachowaniu się amplitudy przemieszczeń, tłumienia i sił. Prowadzone analizy dotyczyły dźwigarów ze środnikiem z blachy fałdowej dla różnych sztywności giętych połączeń poniżej wartości siły wzbudzającej.

Słowa kluczowe: dźwigary SIN, połączenia półsztywne, sztywność giętna, lepkosprężysty model materiałowy

Przestano do redakcji:30.05.2015

Przyjęto do druku:1.12.2015

DOI: $10.7862 / \mathrm{rb} .2015 .174$ 